\title{
Consumer Ethnocentrism and Attitudes towards the Domestic and Foreign-Made Dietary Supplements (the Case of Lithuanian Market)
}

\author{
Ingrida Šmaižienè $\dot{ }^{1}$, Rimgailè Vaitkienè ${ }^{2},{ }^{1,2}$ Kaunas University of Technology
}

\begin{abstract}
The paper aims to disclose the relationship between the consumer ethnocentrism and consumer attitudes towards the domestic and foreign-made dietary supplements in the market of Lithuania. The research data have been obtained by using the survey of consumers.

The data collected during the research disclose the level of consumers' ethnocentrism in the Lithuanian market as well as coherence of consumer ethnocentrism to the perceived quality, safety to use and price of national and imported dietary supplements. The article reveals how the factors influencing the choice of dietary supplements vary in consumers' groups with different level of ethnocentrism.
\end{abstract}

Keywords-Consumer behaviour, consumer ethnocentrism, country-of-origin, dietary supplements.

\section{INTRODUCTION}

Despite increasing consumers' cosmopolitism, consumer ethnocentrism remains a significant issue in international business and marketing in order to better know consumer behaviour. The ethnocentrism involves the belief that one group of the population is superior to others [1]. The ethnocentrism is considered as the expression of the need of a person to pursue one's own identity, to belong to any group and contribute to the well-being of that group [2].

In the marketplace consumer ethnocentrism manifests in consumers' belief that buying of foreign-made products is inappropriate and immoral and may hurt national businesses and employment [3], [4]. Transferred to economic actions such ethnocentric attitude influences consumers' attitude towards the national and foreign-made products, product perceptions and purchase decisions [5].

Reference [6] shows that ethnocentric attitudes disperse across different product categories and different countries. This calls for a product-specific and regional-specific approach while analyzing the phenomenon of consumer ethnocentrism. Product-specific approach means that the influence of consumers' ethnocentrism on the perception of a product, consumer's decisions and actions differ in different categories of goods. Consumers are more sensitive to the country-of-origin of the products that are consumed directly [7] and the consumption of which is more related to physical risk - food, drinks, etc. In this research the product category of dietary supplements have been chosen, as the dietary supplements present a group of products that are consumed directly and are related to more physical risk when compared to other groups of products.
Regional-specific approach leads to searching for some common tendencies in the countries which possess economical, historical and/or cultural similarities. In post-soviet countries the consumer values and attitudes, including consumer ethnocentrism, were inevitably shaped by such factors as centrally planned economy, import restrictions and lack of international competition, limited advertising and sales promotion techniques in the past [8], [9], as well as recent liberalization of economies and integration into the European Union.

The results of the studies on the effect of product's country of origin and manifestation of ethnocentrism in transitional economies are controversial. Reference [9] shows that after 1998, when "the iron curtain" fell, consumers felt great passion for foreign-made products. In post-communist countries consumers queued up to purchase foreign-made products because most of the products that had been deficit in the centrally planned economy [10] became available. Campaigns of unusual advertising and purchase stimulation induced the demand for foreign-made products; the abovementioned promotional factors were hardly used by local companies. When local producers have learnt how to compete with foreign-made products the post-communist consumer again returns back to domestic products [9].

Reference [8] points out that in domestic markets the advertising of the products by means of mass media was hardly used as the way to promote sales. However, according to the reference [8], consumers of post-communist countries met advertisements of foreign products with scepticism.

In this research Lithuanian market was chosen as an example of post-soviet country and transition economy in the Central and Eastern Europe. The article presents the scientific problem - how consumers' ethnocentrism manifests in the market of dietary supplements in Lithuania.

This study aims to disclose the relationship between the consumer ethnocentrism and consumer attitudes towards the domestic and foreign-made dietary supplements in the market of Lithuania.

The following research questions are being discussed in the study: what is the level of consumer ethnocentrism in the Lithuanian market; what is the relationship between consumer ethnocentrism and consumer attitudes towards the domestic and imported dietary supplements; what is the relationship between the consumer ethnocentrism and the importance of the factors influencing decisions on dietary supplements? 
The research methods applied are consumer survey $(N=352)$ and statistical analysis.

The paper consists of three parts. The first part presents theoretical insight on the topic of consumer ethnocentrism, as well as formulates and substantiates hypotheses. The second part presents the research logic and applied research methods. The third part presents research results and the survey of hypotheses.

The research results have been presented at the international scientific conference ICEM 2014 (Riga, Latvia).

\section{THEORETICAL BACKGROUND AND RESEARCH HYPOTHESES}

\section{A. Antecedents of Consumer Ethnocentrism}

The findings of previous empirical studies indicate that the level of consumer ethnocentrism depends on demographic, socio-psychological characteristics of consumers, as well as economical and political characteristics of the export country [11], [12], [13], [14].

Most empirical researches show strong coherence of the degree of consumers' ethnocentrism with demographic characteristics - consumer's education, age and household income. Younger and more educated consumers are considered to be less ethnocentric and have more favourable attitude towards foreign-made products when compared to older customers and the ones with lower education [15], [16]. Consumers with lower-income and lower-education are considered to be more ethnocentric [17], have stronger negative attitude towards purchasing imported products and more keen to avoid foreign-made products. Hence, the following hypotheses are proposed:

Hla: In the market of dietary supplements consumer ethnocentrism is positively related to the consumers' age.

$H 1 b$ : In the market of dietary supplements consumer ethnocentrism is negatively related to the consumers' education.

H1c: In the market of dietary supplements consumer ethnocentrism is negatively related to the consumers' income.

\section{B. Consumer Ethnocentrism as a Determinant of Product Perception}

In the marketplace consumers' ethnocentric attitudes determine not only moral obligation to purchase domestic products but also perceptions of the product [18], [19]. Consumers with high ethnocentrism tend to rate higher the products produced in the domestic market [8], [20], [21] or even to pay premium prices for locally produced products [7]. Such consumers treat imported products as the ones with lower quality and decreased equity [11], [12]. Strong ethnocentrism can determine overestimation of locally-made products or underestimation of the imported products [13], [22].

Based on the above premises, we propose the following hypothesis:

$H 2 a$ : Consumers with high level of consumer ethnocentrism have more favourable perception of dietary supplements manufactured in Lithuania in comparison with consumers with low level of consumer ethnocentrism.
Consumers with high ethnocentrism perceive imported products as threat for local economics and employment [3]. Reference [6] shows that a country's economic competitiveness is one of the factors determining the manifestation of ethnocentrism in consumer behaviour. Country's economical development and competitiveness show the capacity of the country to compete globally and to offer attractive products for foreign markets. Thus it is possible to draw the premise that the higher economical development of the country importing the products, the higher the threat is felt by consumers with high ethnocentrism. In other words, the higher development of the country that produces an imported product, the less ethnocentric consumers are subject to purchase the products imported from that country [23].

\section{This leads to the next hypothesis.}

Hypothesis 2b: The higher the degree of consumer ethnocentrism, the less favourable the consumers' attitude towards dietary supplements produced in high economical development countries is.

Reference [24] shows that ethnocentric consumers are more likely to buy products made in culturally similar countries if locally-made products are not available. For the consumers with high degree of ethnocentrism the products produced in culturally similar countries are the first choice when a domestic alternative is not available [23]. It is possible to draw the premise that consumers high in consumer ethnocentrism have more favourable perceptions of the products produced in geographically and culturally close countries.

However, the data of empirical studies reflecting Lithuanian consumers' attitudes towards the products produced in neighbouring and culturally and historically close countries are controversial. Reference [17] shows that Lithuanian consumers do not have favourable attitude towards the products produced in neighbouring countries: the products made in the neighbouring countries (Russia, Poland, Latvia, and Estonia) received the lowest ratings in the research. Referring to the above-mentioned facts, it is purposeful to formulate the question whether such negative attitude of Lithuanian consumers towards the products produced in neighbouring and/or the countries with cultural, economical and historical similarities are determined by ethnocentrism. Hence the next hypothesis.

$H 2 c$ : The higher the degree of consumer ethnocentrism, the less favourable consumers' attitude towards dietary supplements produced in economically, culturally and historically close countries is.

\section{Consumer Ethnocentrism and the Importance of Product's Country of Origin in Purchase Decision-Making}

The previous research suggests that consumer ethnocentrism might be used for predicting the importance placed on a product's country-of origin. Reference [17] shows that in the Lithuanian market the importance of product's country-oforigin is higher for ethnocentric consumers than for nonethnocentric consumers. 
As reference [12] shows, consumers high in ethnocentrism pay more attention to the country-of-origin cue. Consumers with low ethnocentrism are not particularly concerned with the moral obligation to purchase domestic products [20]. Therefore, in the process of making purchase decisions nonethnocentric consumers pay more attention to more product attributes than to a product's country-of-origin [13].

Thus, when analyzing consumer ethnocentrism in the market of dietary supplements, we developed hypothesis $H 3 a$.

H3a: The higher the degree of consumer ethnocentrism, the more important product's country of origin and less important objective characteristics of a product are for consumers in making decisions on the purchase of dietary supplements.

The data of the research in the Lithuanian market show that for consumers with high ethnocentrism the price is more important than for the consumers with low degree of ethnocentrism [17]. When performing the research on consumers' ethnocentrism in the market of dietary supplements, the following hypothesis was formulated.

$H 3 b$ : The higher the degree of consumer ethnocentrism, the more important the product price is for consumers making decisions on the purchase of dietary supplements.

\section{Methodology}

\section{A. Sample Characteristics}

The sample comprises the data on 352 consumers who are older than 18 years and purchase dietary supplements. The group of consumers of the sample included $87.5 \%$ of women and $12.5 \%$ of men. Other characteristics of the sample are presented in Table I.

TABLE I

SAMPLE CHARACTERISTICS

\begin{tabular}{|c|c|c|}
\hline $\begin{array}{l}\text { Socio-demographic } \\
\text { characteristics }\end{array}$ & Frequency & Percentage \\
\hline \multicolumn{3}{|l|}{ Age: } \\
\hline Up to 20 years & 15 & 4.3 \\
\hline $20-29$ years & 122 & 34.7 \\
\hline $30-39$ years & 93 & 26.4 \\
\hline $40-49$ years & 70 & 19.9 \\
\hline $50-59$ years & 39 & 11.1 \\
\hline 60 years and more & 13 & 3.6 \\
\hline \multicolumn{3}{|l|}{ Education: } \\
\hline Basic & 5 & 1.4 \\
\hline Secondary & 56 & 15.9 \\
\hline Vocational & 10 & 2.8 \\
\hline College & 43 & 12.2 \\
\hline University & 238 & 67.7 \\
\hline \multicolumn{3}{|l|}{$\begin{array}{l}\text { Monthly income per } \\
\text { household, Lt: }\end{array}$} \\
\hline Up to 1000 & 34 & 9.7 \\
\hline $1001-2000$ & 73 & 20.7 \\
\hline $2001-3000$ & 85 & 24.1 \\
\hline $3001-4000$ & 62 & 17.6 \\
\hline $4001-5000$ & 47 & 13.4 \\
\hline More than 5000 & 47 & 13.4 \\
\hline No answer & 4 & 1.1 \\
\hline
\end{tabular}

\section{B. Data Collection and Measures}

Data for this study were collected by means of survey in written form and a coordinated survey online throughout Lithuania in April 2013.

The level of consumer ethnocentrism was measured with the help of consumer ethnocentric tendencies scale (CETSCALE) [3]. The original version of 17-item CETSCALE was modified and shortened to the 12-item scale (see Table II). The 6-item scale (where 1 means - strongly disagree; 6 - strongly agree) was used. The internal consistency of the scale was excellent (Cronbach's alpha $=0.917$ )

When analyzing the data collected by means of this scale, four groups of respondents having different level of ethnocentric attitude were distinguished - from low level of consumer ethnocentrism to high level of consumer ethnocentrism.

In order to survey consumers' perceptions about the dietary supplements manufactured in Lithuania and foreign countries, three scales were used. The first seven-point scale was applied to analyze the quality of dietary supplements perceived by consumers ( 1 - very low quality; 7 -very high quality). Internal consistency of this scale was excellent (Cronbach's alpha $=0.923$ ). The second scale was aimed to measure consumer perceptions about the safety of domestic and imported dietary supplements. The three-point scale $(1-$ not safe to use a product; 2 -doubt about a product safety; 3 - confident about a product safety) was applied. Internal consistency of the scale was good (Cronbach's alpha $=0.858$ ). The third scale was meant to measure the perception of dietary supplements' price. Seven-point scale (1 - very low price; 7 very high price) was used. Referring to the Cronbach's alpha coefficient, internal consistency of the scale was excellent (0.962).

The ten-point scale was used to determine the importance of different factors influencing the decisions on dietary supplements' choice and purchase ( 1 - absolutely unimportant; 10 - very important). Cronbach's alpha coefficient (0.842) showed good internal consistency of this scale.

When analyzing the data, the factors, the importance of which was evaluated by the mean from 1 to 4 , have been assigned to the group of low importance factors. The factors, the importance of which was evaluated by the mean from 4 to 7 , have been assigned to the group of medium importance factors. The factors, the importance of which were defined by the mean from 7 to 10 , have been assigned to the group of high importance factors.

During the data analysis, the correlations between consumers' ethnocentrism and their demographic characteristics, consumers' ethnocentrism and product characteristics perceived by consumers, as well as the importance of the factors influencing purchase decisions were analyzed. 
TABLE II

THE LEVEL OF CONSUMER ETHNOCENTRISM

\begin{tabular}{|c|c|c|}
\hline & Mean $^{\mathrm{a}}$ & Std. Deviation \\
\hline a. Lithuanians should always buy Lithuanian-made products instead of imported & 2.90 & 1.370 \\
\hline b. Only those products that are unavailable in Lithuania should be imported & 2.82 & 1.396 \\
\hline c. Even if the price is higher, Lithuanians should choose Lithuanian-made products & 2.71 & 1.225 \\
\hline d. Curbs should be put on all imports & 2.34 & 1.259 \\
\hline e. It is not right to purchase foreign-made products & 2.19 & 1.151 \\
\hline f. There should be very little purchasing of foreign-made products unless out of necessity & 2.52 & 1.292 \\
\hline g. Lithuanians should not buy foreign products, because it harms Lithuanian business and causes unemployment & 2.48 & 1.290 \\
\hline h. Lithuanians should purchase products manufactured in Lithuania instead of letting other countries get rich off us & 2.59 & 1.402 \\
\hline i. Lithuanian products are the best ones & 2.75 & 1.216 \\
\hline j. Products manufactured in Lithuania are more reliable & 3.61 & 1.138 \\
\hline k. Products manufactured in Lithuania are more natural & 3.62 & 1.115 \\
\hline 1. Prices of the products manufactured in Lithuania are more favourable & 3.80 & 1.179 \\
\hline
\end{tabular}

a- means on the 6-point scale, where 1means - strongly disagree; 6 - strongly agree

\section{RESEARCH RESULTS AND TESTING OF HYPOTHESES}

\section{A. Ethnocentrism Level and the Relationship with Socio- Demographic Characteristics}

The data collected during the survey (see Table II) show that in the Lithuanian market consumers' ethnocentrism is less than moderate (the mean 2.86 on the 6-point scale). The statements a-h got less than average approval of the respondents (the mean ranges from 2.19 to 2.90). It is possible to state that the respondents inclined to oppose that buying imported products is inappropriate and may hurt local businesses and employment.

The statements $i-1$ estimating consumers' attitudes to Lithuanian products got higher approval of the respondents (the mean ranges from 2.75 to 3.80 ). This confirms that the respondents' attitudes towards reliability, naturalness of Lithuanian products and their prices are more positive than negative.

Having performed the correlation analysis between the strength of consumers' ethnocentrism and socio-demographic characteristics, it was identified that the ethnocentric attitudes become stronger when the respondents' age increases $(r=0.022)$ and it decreases when their education increases $(r=-0.101)$ and the monthly income per household increases $(r=-0.191)$. However, the statistically reliable correlation was identified only between the consumer ethnocentrism and household income: the less the household income, the stronger attitude of consumers' ethnocentrism is.

Referring to the data presented above, the hypotheses Hla and $H 1 b$ have been denied. The hypothesis Hlc has been confirmed.

\section{B. Consumer Ethnocentrism and the Attitude towards Local and Foreign-Made Dietary Supplements}

Referring to the data presented in Table III, it is possible to state that the respondents of this survey perceive the dietary supplements produced in the countries of high economic development as ones of better quality (means range from 6.14 to 5.19) and more secure to consume (means range from 2.94 to 2.74). In other words, consumer attitudes towards the dietary supplements produced in these countries are more favourable in comparison to the attitude to the dietary supplements produced in the countries with historical, cultural and economical similarities (evaluations of the perceived quality 4.95-3.91; evaluations of the perceived safety to consume $2.49-1.93$ ) and in developing geographically remote countries (evaluations of the perceived quality 4.14-3.51; evaluations of the perceived safety to consume $1.72-1.56$ ).

The prices of the dietary supplements produced in highly economically developed countries are perceived as the highest. Prices of the dietary supplements produced in the countries with cultural, geographical and economical similarities, as well as in the geographically remote developing countries are perceived as much lower.

The analysis of scientific literature has shown that consumers high in ethnocentrism are inclined to overestimation of the products produced in their country. The analysis of the research data has shown that the respondents perceive the quality and safety of the dietary supplements produced in Lithuania as much better than of the dietary supplements produced in the countries with historical, cultural or economical similarities. The prices of the dietary supplements produced in Lithuania are also perceived as higher than in the countries assigned to the group of close countries. The respondents perceive the quality, prices and safety to consume of the dietary supplements produced in Lithuania similarly as of the dietary supplements produced in the high economical development countries.

The analysis of scientific literature has shown that the consumers with stronger ethnocentrism are inclined to express worse attitude to the products produced in economically developed countries. The correlation analysis of the research has shown statistically reliable negative links between the consumer ethnocentrism level and the perceived quality of the dietary supplements produced in the developed countries (Germany, Switzerland, USA, Great Britain) (respectively 
TABLE III

RELATIONSHiP BetweEn THE CONSUMER ETHNOCENTRISM AND PRODUCT PERCEPTION

\begin{tabular}{|c|c|c|c|c|c|c|}
\hline & \multicolumn{2}{|c|}{ Perceived quality } & \multicolumn{2}{|c|}{ Perceived safety } & \multicolumn{2}{|c|}{ Perceived price } \\
\hline $\begin{array}{l}\text { Dietary supplements } \\
\text { manufactured in... }\end{array}$ & Mean $^{\mathrm{b}}$ & $\begin{array}{l}\text { Ethnocentrism - } \\
\text { Perceived quality }\end{array}$ & Mean $^{\mathrm{c}}$ & $\begin{array}{c}\text { Ethnocentrism } \\
\text { - Perceived } \\
\text { safety }\end{array}$ & Mean $^{\mathrm{d}}$ & $\begin{array}{l}\text { Ethnocentrism - } \\
\text { Perceived price }\end{array}$ \\
\hline \multicolumn{7}{|c|}{ Group I: high economic development countries } \\
\hline Germany & 6.14 & $-.203^{* *}$ & 2.93 & -.054 & 5.51 & -.025 \\
\hline Switzerland & 6.11 & $-.181^{*}$ & 2.94 & -.095 & 5.72 & -.047 \\
\hline Scandinavian countries & 6.02 & -.120 & 2.87 & $-.194^{*}$ & 5.40 & -.117 \\
\hline USA & 5.86 & $-.266^{* *}$ & 2.75 & -.053 & 5.35 & 106 \\
\hline France & 5.77 & .009 & 2.86 & $-.179^{*}$ & 5.38 & -.114 \\
\hline Japan & 5.69 & -.153 & 2.74 & $-.255^{* *}$ & 5.46 & -.233 \\
\hline Great Britain & 5.46 & $-.247^{\text {** }}$ & 2.85 & .030 & 5.15 & -.027 \\
\hline Belgium & 5.20 & -.037 & 2.76 & $-.212^{*}$ & 5.08 & -.153 \\
\hline Netherlands & 5.19 & -.148 & 2.78 & $-.255^{* *}$ & 5.02 & -.086 \\
\hline \multicolumn{7}{|c|}{ Group II: countries with historical, cultural and/or economical similarities } \\
\hline Lithuania & 5.47 & $.178^{* *}$ & 2.72 & .109 & 4.66 & -.037 \\
\hline Slovenia & 4.95 & -.020 & 2.49 & -.004 & 4.26 & .051 \\
\hline Russia & 4.86 & .074 & 2.13 & -.024 & 3.30 & .011 \\
\hline Poland & 4.13 & .059 & 2.14 & -.054 & 3.65 & 119 \\
\hline Ukraine & 3.91 & .183 & 1.93 & .086 & 3.35 & -.032 \\
\hline \multicolumn{7}{|c|}{ Group III: developing geographically remote countries } \\
\hline India & 4.14 & $.233^{*}$ & 1.72 & -.008 & 3.86 & 244 \\
\hline China & 3.51 & .076 & 1.56 & -.118 & 3.62 & .000 \\
\hline
\end{tabular}

b- means on the 7-point scale where 1 - very low quality; 7 - very high quality; c- means on the 3 -point scale where 1 - not safe to use a product;

2 - doubt about a product safety; 3 - confident about a product safety; d- means on the 7-point scale where 1 - very low price; 7 - very high price.

* Correlation is significant at the 0.05 level (2-tailed); ** Correlation is significant at the 0.01 level (2-tailed).

$r=-0.203 ;-0.181 ;-0.266 ;-0.247)$. In other words, the stronger the consumers' ethnocentric attitudes, the worse perceived quality of the dietary supplements produced in the above-mentioned countries is.

The research data have shown statistically reliable negative correlation links between the consumers' ethnocentrism and the perceived safety of the dietary supplements produced in Scandinavian countries, France, Japan, Belgium and Netherlands (respectively $r=-0.194 ;-0.179 ;-0.255 ;-0.212$; $-0.255)$. In other words, the stronger the consumers' ethnocentric attitudes, the worse they are inclined to evaluate the consumption safety of the dietary supplements produced in these countries.

During the research the statistically reliable positive relationship between the level of consumer ethnocentrism and the perceived quality of the dietary supplements produced in Lithuania have been identified $(r=0.178)$. The stronger the consumer ethnocentrism, the more favourable consumers' attitude towards the quality of the dietary supplements produced in local economy is.

Referring to the above-presented data, the hypothesis $H 2 a$ is supported partially. The greater the consumer ethnocentrism, the more favourable consumer attitude towards the quality of the dietary supplements produced in Lithuania is. The statistically reliable correlations among consumers' ethnocentrism and the perceived safety of domestic dietary supplements, as well as favourable perceived price have not been identified.

The hypothesis $\mathrm{H} 2 b$ is supported. The stronger the consumer ethnocentrism, the more unfavourable consumer attitude towards the quality of the dietary supplements produced in high economical development countries or their safety to use is.

The hypothesis $H 2 c$ is denied. The research data show that Lithuanian consumers perceive the dietary supplements produced in the countries with economical, cultural or historical similarities as worse than the dietary supplements produced in highly development countries and Lithuania. However, during this research there have not been found any statistically reliable correlation between consumer ethnocentrism and attitude towards the dietary supplements produced in countries with historical, cultural and/or economic similarities.

C. Consumer Ethnocentrism and the Importance of the Factors Influencing the Decisions on Purchase of Dietary Supplements

When analyzing the relationship between the consumers' ethnocentrism and the importance of the factors influencing the choice of dietary supplements (see Table IV), the 
statistically reliable positive correlation between the strength of consumer ethnocentrism and the importance of Lithuanian brand name when making decisions on the purchase of dietary supplements has been identified $(r=0.401)$.

The research data have shown that in all four groups of the respondents with different level of ethnocentrism (Fig. 1) the well-known brand of dietary supplements is more important than Lithuanian brand name.

In the group of low ethnocentrism respondents the countryof-origin of dietary supplements is a bit more important than the well-known brand (Fig. 1). Both these factors: well-known brand and product's country of origin are much more important than the Lithuanian brand name.

In the groups of the respondents with less than average and higher than average ethnocentrism the country of origin of dietary supplements is a bit more important than the wellknown brand. In the group of the respondents with high ethnocentrism the well-known brand is much more important than the country of origin of dietary supplements; Lithuanian brand name is more important than product's country-of-origin.

The research data have shown that the stronger the consumer ethnocentrism, the more important the factors related to the price when choosing dietary supplements are for him / her. Statistically reliable positive correlation between the strength of consumers' ethnocentrism and the factors related to the price - the offered discount $(r=0.218)$, large amount for reasonable price $(r=0.166)$ and price $(r=0.142)$ - have been identified.

The research data show that the stronger the consumer ethnocentrism the more important advertising $(r=0.247)$, attractive packaging $(r=0.212)$ and comprehensive presentation on $\mathrm{TV}$, radio or press $(r=0.185)$ are for them. Also there have been identified statistically reliable positive correlation between the strength of consumer ethnocentrism and the importance of recommendations of a pharmacist $(r=0.206)$, as well as doctor's recommendations $(r=0.189)$. The group of the high ethnocentrism respondents named the doctor's recommendations as the most important factor in choosing dietary supplements (Fig. 1).

When analyzing the importance of the factors influencing the choice of dietary supplements in consumers' groups with different ethnocentrism (Fig. 1), it has been identified that in all four groups personally tested quality is among the most important factors (the importance ranges from 8.37 to 9.27 on the 10-point scale). Product naturalness is attributed to important factors. As consumer ethnocentrism strengthens, the importance of this factor increases (respectively from 7.16 in the group of low ethnocentrism respondents to 8.94 in the group of high ethnocentrism respondents). Price is also attributed to the group of the factors influencing the decisions on the purchase of dietary supplements. As consumer ethnocentrism strengthens, price importance increases from 7.89 in the group of low ethnocentrism respondents to 8.69 in the group of high ethnocentrism respondents.

The number and variety of vitamins and supplements in the composition of a product is also named as one of the most important factors in all four groups of the respondents. The importance of this factor ranges from 7.01 among the respondents of the lower than average ethnocentrism level to 8.40 among the respondents of high ethnocentrism level.

The research results show that the higher the level of consumer ethnocentrism, the more factors the respondents name as very important. In the group of the respondents with low ethnocentrism six factors have been assigned as very important, eight factors - in the group of less than average ethnocentrism, ten factors - in the group of the respondents

TABLE IV

RELATIONSHIP BETWEEN CONSUMER ETHNOCENTRISM AND THE IMPORTANCE OF THE FACTORS INFLUENCING PURCHASE DECISIONS

\begin{tabular}{|c|c|c|c|}
\hline $\begin{array}{l}\text { Factors influencing decisions on purchase of dietary } \\
\text { supplements }\end{array}$ & $\begin{array}{l}\text { Correlation } \\
\text { coefficient }\end{array}$ & $\begin{array}{l}\text { Factors influencing decisions on purchase of dietary } \\
\text { supplements }\end{array}$ & $\begin{array}{l}\text { Correlation } \\
\text { coefficient }\end{array}$ \\
\hline \multicolumn{2}{|l|}{ I. Factors related to price } & \multicolumn{2}{|l|}{ IV. External marketing communication } \\
\hline - Offered discount & $.218 * *$ & - Advertising & $.247 * *$ \\
\hline - Large amount for reasonable price & $.166^{* * *}$ & - Attractive packaging & $.212 * *$ \\
\hline - Price & $.142 *$ & - Comprehensive presentation on $\mathrm{TV}$, radio or in press & $.185^{* *}$ \\
\hline \multicolumn{2}{|l|}{ II. Factors related to brand name and country-of-origin } & \multicolumn{2}{|l|}{ V. Product characteristics } \\
\hline - Lithuanian brand name & $.401 * *$ & $\begin{array}{l}\text { - The number and variety of vitamins and } \\
\text { supplements in the composition of a product }\end{array}$ & .098 \\
\hline - Well-known brand & -.022 & - How many capsules per day it is necessary to apply & .086 \\
\hline - Product's country of origin & -.034 & - Large amount of the active substance of interest & .082 \\
\hline \multicolumn{2}{|l|}{ III. Personal experience and recommendations } & - How many times per day it is necessary to apply & 080 \\
\hline - Recommendations of a pharmacist & $.206 * *$ & - Expiry date & .059 \\
\hline - Doctor's recommendations & $.189 * *$ & - Product ecology & .023 \\
\hline - Consumers' comments in the Internet & .106 & - Product naturalness & -.001 \\
\hline - Recommendations of friends and acquaintances & .102 & & \\
\hline - Personally tested quality & -.091 & & \\
\hline
\end{tabular}

* Correlation is significant at the 0.05 level (2-tailed); ** Correlation is significant at the 0.01 level (2-tailed). 
with higher than average ethnocentrism, twelve factors - in the group of high ethnocentrism; they influence the choice of dietary supplements.

And conversely: the lower the level of ethnocentrism, the more factors the respondents name as less important in making decisions on purchase of dietary supplements. Among the respondents with low ethnocentrism this group involves four factors, in the group of lower than average ethnocentrism three factors, in the group of higher than average ethnocentrism two factors. Such factors have not been identified in the group of the respondents with high ethnocentrism.

As the level of ethnocentrism increases, the importance of recommendations by a doctor, pharmacist and friends, as well as acquaintances and the importance of proper presenting a product in mass media increase. Thus it is possible to draw the premise that the higher the level of consumer ethnocentrism the greater influence external factors make upon decisions on buying dietary supplements.

Referring to the above-presented data, the hypothesis $H 3 a$ is denied. The country-of-origin of a product is attributed to the group of moderate importance factors. Statistically reliable relationship between the consumer ethnocentrism and the importance of product's country-of-origin when purchasing dietary supplements has not been identified.

As consumer ethnocentrism strengthens, the importance of Lithuanian brand name when a consumer makes decisions on buying dietary supplements increases. However, it is necessary to point out that not always the products marked in Lithuanian lettering are produced in local economy. Sometimes the imported dietary supplements are marked in Lithuanian lettering in order to use this as a marketing instrument.

The higher the consumer ethnocentrism, the more is the importance of objective characteristics of a product (the number and variety of vitamins and supplements in the composition of a product, number of capsules to be applied per day, large amount of the active substance of interest, expiry date, product ecology). However, statistically reliable correlation between the consumer ethnocentrism and the importance of these factors has not been identified. The research results show that the higher the consumer ethnocentrism the more important the information and recommendations transmitted by means of marketing communication are for a consumer.

The hypothesis $H 3 b$ is supported. The higher the level of the consumer ethnocentrism the more important the product's price, offered discount and large amount for reasonable price is for consumers when making decisions on buying dietary supplements

\section{CONCLUSION}

In Lithuania's market consumer ethnocentrism is lower than average. Consumers' attitude towards the import of products and purchase of imported products is not negative. The attitude towards reliability and naturalness of Lithuanian products is positive. The research results confirm the theoretical approach that the lower consumers' household income the stronger their ethnocentrism is.

The findings of the research performed in Lithuania's market of dietary supplements indicate that the higher the level of consumer ethnocentrism the better the consumers' opinion is about the quality of dietary supplements produced in Lithuania. The perception of the quality of dietary supplements produced in Lithuania, their safety to use and price much differs from the perceptions of dietary supplements produced in the countries with historical, cultural or economical similarities. It is possible to draw the premise that Lithuanian consumers are subject to the overestimation of the quality of the dietary supplements produced in local economy. The perception of the quality, price and safety of the dietary supplements produced in Lithuania is close to the perception of the dietary supplements produced in the countries of high economic development.

The stronger the consumer ethnocentric approach the worse the attitude towards the quality of the dietary supplements produced in Germany, Switzerland, the USA and Great Britain, and the safety of the dietary supplements produced in Scandinavian countries, France, Japan, Belgium and the Netherlands is.

Personally tested quality, price and product naturalness get into the four most important factors when choosing dietary supplements in all groups of the respondents with different level of consumer ethnocentrism. The importance of other factors varied in the distinguished groups of the respondents.

The stronger the consumer ethnocentrism, the more factors the consumers are subject to name as very important and important in making decisions on the purchase of dietary supplements. The higher the level of consumer ethnocentrism, the more important the factors related to decisions on the purchase of dietary supplements, external marketing communication, recommendations of a doctor and pharmacist, as well as Lithuanian brand name are.

In groups of the respondents with different level of ethnocentrism well-known brand is more important than Lithuanian brand name. in the group of the respondents with high consumer ethnocentrism level the Lithuanian brand name is more important than the product's country of origin. It is possible to explain this by the fact that some companies importing dietary supplements use local brand names adapted for Lithuanian market with Lithuanian captions.

The ethnocentrism of Lithuania's consumers does not explain why dietary supplements produced in the countries with cultural and historical similarities are perceived as much worse than the ones produced in Lithuania. In order to explain this phenomenon it is purposeful to carry out the research on consumer animosity towards the neighbouring countries. 


\begin{tabular}{|c|c|c|c|c|}
\hline 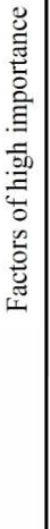 & $\begin{array}{l}\text { - Personally tested quality } 8.37 \\
\text { - Price } 7.89 \\
\text { - Naturalness } 7.16 \\
\text { - The number and variety of vitamins } \\
\text { and supplements in the composition } \\
\text { of a product } 7.11 \\
\text { - Large amount of the active substance } \\
\text { of interest } 7.06\end{array}$ & $\begin{array}{l}\text { - Personally tested quality } 9.27 \\
\text { - Naturalness } 8.42 \\
\text { - Price } 7.90 \\
\text { - Expiry date } 7.89 \\
\text { - Product ecology } 7.78 \\
\text { - Doctor's recommendations } 7.54 \\
\text { - Offered discount } 7.38 \\
\text { - The number and variety of vitamins } \\
\text { and supplements in the composition } \\
\text { of a product } 7.01\end{array}$ & $\begin{array}{l}\text { - Personally tested quality } 9.07 \\
\text { - Naturalness } 8.43 \\
\text { - Price } 8.26 \\
\text { - Offered discount } 7.95 \\
\text { - Expiry date } 7.90 \\
\text { - Product ecology } 7.88 \\
\text { - Doctor's recommendations } 7.64 \\
\text { - Large amount of the active substance } \\
\text { of interest } 7.45 \\
\text { - The number and variety of vitamins } \\
\text { and supplements in the composition of } \\
\text { a product } 7.42 \\
\text { - Large amount for reasonable price } 7.07\end{array}$ & $\begin{array}{l}\text { - Doctor's recommendations } 9.06 \\
\text { - Naturalness } 8.94 \\
\text { - Personally tested quality } 8.88 \\
\text { - Price } 8.69 \\
\text { - Offered discount } 8.69 \\
\text { - The number and variety of vitamins } \\
\text { and supplements in the composition of } \\
\text { a product } 8.40 \\
\text { - Expiry date } 7.88 \\
\text { - Product ecology } 7.69 \\
\text { - Large amount of the active substance of } \\
\text { interest } 7.60 \\
\text { - Recommendations of a pharmacist } 7.14 \\
\text { - Large amount for reasonable price } 7.13 \\
\text { - Well-known brand } 7.13\end{array}$ \\
\hline 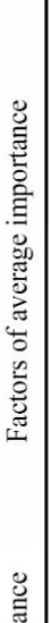 & $\begin{array}{l}\text { - Product ecology } 6.74 \\
\text { - Offered discount } 6.72 \\
\text { - Product's country of origin } \mathbf{6 . 2 8} \\
\text { - Expiry date } 6.21 \\
\text { - Well-known brand } 6.16 \\
\text { - Doctor's recommendations } 5.94 \\
\text { - How many capsules per day it is } \\
\text { necessary to apply } 5.79 \\
\text { - How many times per day it is } \\
\text { necessary to apply } 5.74 \\
\text { - Large amount for reasonable price } \\
5.72 \\
\text { - Consumers' comments in the Internet } \\
5.28 \\
\text { - Recommendations of friends and } \\
\text { acquaintances } 5.11 \\
\text { - Recommendations of a pharmacist } \\
4.89\end{array}$ & $\begin{array}{l}\text { - Large amount of the active substance } \\
\text { of interest } 6.93 \\
\text { - Recommendations of friends and } \\
\text { acquaintances } 6.54 \\
\text { - Large amount for reasonable price } \\
6.42 \\
\text { - Product's country of origin } \mathbf{6 . 1 8} \\
\text { - Recommendations of a pharmacist } \\
6.18 \\
\text { - Well-known brand } 6.11 \\
\text { - How many times per day it is } \\
\text { necessary to apply } 5.89 \\
\text { - How many capsules per day it is } \\
\text { necessary to apply } 5.87 \\
\text { - Consumers' comments in the } \\
\text { Internet } 5.30 \\
\text { - Lithuanian brand name } 4.23\end{array}$ & $\begin{array}{l}\text { - Recommendations of a pharmacist } \\
6.69 \\
\text { - Recommendations of friends and } \\
\text { acquaintances } 6.61 \\
\text { - How many times per day it is } \\
\text { necessary to apply } 6.32 \\
\text { - How many capsules per day it is } \\
\text { necessary to apply } 6.31 \\
\text { - Product's country of origin } \mathbf{6 . 1 7} \\
\text { - Well-known brand } \mathbf{5 . 9 3} \\
\text { - Lithuanian brand name } \mathbf{5 . 8 4} \\
\text { - Consumers' comments in the Internet } \\
\text { 5.30 } \\
\text { - Comprehensive presentation on TV, } \\
\text { radio or in press } 4.04\end{array}$ & $\begin{array}{l}\text { - Recommendations of friends and } \\
\text { acquaintances } 6.93 \\
\text { - How many times per day it is necessary } \\
\text { to apply } 6.87 \\
\text { - Consumers' comments in the Internet } \\
6.80 \\
\text { - How many capsules per day it is } \\
\text { necessary to apply } 6.67 \\
\text { - Lithuanian brand name } \mathbf{6 . 4 4} \\
\text { - Advertising } 6.19 \\
\text { - Product's country of origin } \mathbf{5 . 6 7} \\
\text { - Comprehensive presentation on TV, } \\
\text { radio or in press } 5.67 \\
\text { - Attractive packaging } 4.13\end{array}$ \\
\hline 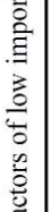 & $\begin{array}{l}\text { - Comprehensive presentation on TV, } \\
\text { radio or in press } 3.22 \\
\text { - Advertising } 2.72 \\
\text { - Lithuanian brand name } 2.61 \\
\text { - Attractive packaging } 2.56\end{array}$ & $\begin{array}{l}\text { - Comprehensive presentation on TV, } \\
\text { radio or in press } 3.79 \\
\text { - Advertising } 3.29 \\
\text { - Attractive packaging } 2.73\end{array}$ & $\begin{array}{l}\text { - Attractive packaging } 3.91 \\
\text { - Advertising } 3.89\end{array}$ & \\
\hline
\end{tabular}

Low consumer ethnocentrism

Consumer ethnocentrism below average

Consumer ethnocentrism above average

High consumer ethnocentrism

Fig. 1. The importance of the factors influencing decisions on purchase of dietary supplements in groups of the respondents with different level of ethnocentrism. 


\section{REFERENCES}

[1] Huddleston, P., Good, L. K. and Stoel, L., "Consumer ethnocentrism, product necessity and Polish consumers' perceptions of quality,' International Journal of Retail \& Distribution Management, vol. 29, no. 5, pp. 236-246, 2001. http://dx.doi.org/10.1108/09590550110390896

[2] Brkič, N., Čorbo, M. and Berberovič, D., "Ethnocentrism and animosity in consumer behavior in Bosnia and Herzegovna and implications for companies," Economic Review - Journal of Economics and Business, vol. IX, no 1, pp. 45-61, June 2011.

[3] Shimp, T. A. and Sharma, S., "Consumer ethnocentrism: construction and validation of the CETSCALE," Journal of Marketing Research, vol. XXIV, pp. 280-289, 1987. http://dx.doi.org/10.2307/3151638

[4] Auruskeviciene, V., Vianelli, D. and Reardon, J., "Comparison of consumer ethnocentrism," Transformations in Business \& Economics, vol. 11 , no. 2, pp. 20-35, 2012.

[5] Kaynak, E. and Kara, A., "Consumer perceptions of foreign products: An analysis of product-country images and ethnocentrism," European Journal of Marketing, vol. 36, no. 7/8, pp. 928-949, 2002. http://dx.doi.org/10.1108/03090560210430881

[6] Balabanis, G. and Diamantopoulos, A., "Domestic Country Bias, Country-of-Origin Effects, and Consumer Ethnocentrism: A Multidimensional Unfolding Approach," Journal of the Academy of Marketing Science, vol. 32, no. 1, pp. 80-95, 2004. http://dx.doi.org/10.1177/0092070303257644

[7] Drozdenko, R. and Jensen, M., "Translating country-of-origin effects into prices," Journal of Product \& Brand Management, vol. 18, no. 5, pp. 371-378, pp. 2009. http://dx.doi.org/10.1108/10610420910981855

[8] Reardon, J., Miller, Ch., Vida, I. and Kim, I., "The effects of ethnocentrism and economic development on the formation of brand and ad attitudes in transitional economies," European Journal of Marketing, vol. 39, no. 7/8, pp. 737-754, 2005. http://dx.doi.org/10.1108/03090560510601743

[9] Z. Kreckova, J. Odehnalova and J. Reardon, "Consumer Ethnocentricity within the Environment of Economic Crisis", Inzinerine Ekonomika Engineering Economics, vol. 23, no. 3, pp. 271-281, 2012. http://dx.doi.org/10.5755/j01.ee.23.3.1932

[10] Huddleston, P., Good, L. K. and Stoel, L., "Consumer ethnocentrism, product necessity and quality perceptions of Russian consumers," The International Review of Retail, Distribution and Consumer Research, vol. 10 , no. 2 , pp. $167-181,2000$. http://dx.doi.org/10.1080/095939600342343

[11] Shankarmahesh, M. N., "Consumer ethnocentrism: an integrative review of its antecedents and consequences", International Marketing Review, vol. 23 , no. 2 , pp. 146-172, 2006. http://dx.doi.org/10.1108/02651330610660065

[12] Saffu, K., Walker, J. H. and Mazurek, M., "The role of consumer ethnocentrism in a buy national campaign in a transitioning country: Some evidence from Slovakia," International Journal of Emerging Markets, vol. 5, no. 2, pp. 203-226, 2010. http://dx.doi.org/10.1108/17468801011031829

[13] Cumberland, F. Solgaard, H. S. and Nikodemska-Wolowik, A. M., "The Effects of Consumer Ethnocentrism and Country of Origin on Polish Consumers' Evaluation of Foreign Manufactured Products," Journal of East-West Business, vol. 16, no. 3, pp. 231-252, 2010. http://dx.doi.org/10.1080/10669868.2010.523374

[14] Siemieniako, D., Kubacki, K., Glinska, E. and Krot, K., "National and regional ethnocentrism: a case study of beer consumers in Poland,' British Food Journal, vol. 113, no. 3, pp. 404-418, 2011. http://dx.doi.org/10.1108/00070701111116464

[15] Erdogan, B. Z. and Uzkurt, C., "Effects of ethnocentric tendency on consumers' perception of product attitudes for foreign and domestic products," Cross Cultural Management: An International Journal, vol. 17, no. 4, pp. 393-406, 2010. http://dx.doi.org/10.1108/13527601011086595
[16] Josiassen, A., Assaf, G. and Karpen, I. O., "Consumer ethnocentrism and willingness to buy: Analyzing the role of three demographic consumer characteristics," International Marketing Review, vol. 28, no. 6, pp. 627-646, 2011. http://dx.doi.org/10.1108/02651331111181448

[17] Mockaitis, A. I., Salciuviene, L. and Ghauri, P. N., "On What Do Consumer Product Preferences Depend?" Determining Domestic versus Foreign Product Preferences in an Emerging Economy Market, Journal of International Consumer Marketing, vol. 25, no. 3, pp. 166-180, 2013. http://dx.doi.org/10.1080/08961530.2013.780456

[18] Pecotich, A. and Rosenthal, M. J., "Country of Origin, Quality, Brand and Consumer Ethnocentrism," Journal of Global Marketing, vol. 15, no. 2, pp. 31-60, 2001. http://dx.doi.org/10.1300/J042v15n02 03

[19] Smaiziene, I. and Vaitkiene, R., "Country of Origin Effect in a Lithuanian Market of Vitamins and Dietary Supplements," International Business Research, vol. 6, no. 12, pp. 118-133, 2013. http://dx.doi.org/10.5539/ibr.v6n12p118

[20] Acharya, Ch. and Elliott, G., "Consumer Ethnocentrism, Perceived Product Quality and Choice-An Empirical Investigation," Journal of International Consumer Marketing, vol. 15, no. 4, pp. 87-115, 2003. http://dx.doi.org/10.1300/J046v15n04_05

[21] Carpenter, J. M., Moore, M., Alexander, N. and Doherty, A. M., "Consumer demographics, ethnocentrism, cultural values, and acculturation to the global consumer culture: A retail perspective," Journal of Marketing Management, vol. 29, no. 3/4, pp. 271-29, 2013. http://dx.doi.org/10.1080/0267257X.2013.766629

[22] Sharma, S., Shimp, T. A. and Shin, J., "Consumer ethnocentrism: A test of antecedents and moderators," Journal of the Academy of Marketing Science, vol. 23, no. 1, pp. 26-37, 1995 http://dx.doi.org/10.1007/BF02894609

[23] Evanschitzky, H., Wangenheim, F., Woisetschläger, D. and Blut, M., "Consumer ethnocentrism in the German market," International Marketing Review, vol. 25, no. 1, pp. 7-32, 2008. http://dx.doi.org/10.1108/02651330810851863

[24] Watson, J. J. and Wright, K., "Consumer ethnocentrism and attitudes toward domestic and foreign products," European Journal of Marketing, vol. 34 no. 9/10, pp. 1149-66, 2000. http://dx.doi.org/10.1108/03090560010342520

Ingrida Šmaižienė received the Master's degree in Management and Administration in 2003 from Kaunas University of Technology (KTU). She was a doctoral student in the field of management and administration with KTU from 2005 - 2011

Since 2009, she has been a Lecturer with the Department of Strategic Management, Kaunas University of Technology. She lectures on the subject of Entrepreneurship, Image and Reputation and is an Assistant Lecturer in the study course Business research methods.

Her main fields of scientific interest are: corporate reputation management, reputational capital, country image, and country-of-origin effect.

Address: Donelaicio Str. 20-411, LT-44239 Kaunas, Lithuania.

E-mail: ingrida.smaiziene@ktu.lt

Rimgaile Vaitkienè received the Diploma in Economics from Kaunas Polytechnical Institute in 1989, and the Doctoral Degree in Social Sciences from Kaunas University of Technology in 1998.

From 1995-2000, she has been with the Department of Business Administration. From 2000-2013, she has been an Associate Professor and, since 2014, a Professor with the Department of Strategic Management, Kaunas University of Technology. She lectures on the subject of methodology of social research to undergraduate, graduate and postgraduate students, as well as the on marketing management and consumer behaviour.

Her main fields of scientific interest are: business research methods, consumer behaviour, international marketing, and strategic marketing management.

Address: Donelaicio Str. 20-411, LT-44239 Kaunas, Lithuania.

E-mail: rimgaile.vaitkiene@ktu.lt 